\title{
The Influence of Heroic Leadership and Learning Organization to Work Achievement with Authentic Personal Branding as Mediator
}

\author{
Antonius Dieben Robinson Manurung \\ Mercu Buana University Jakarta \\ E-mail: antoniusmanurung69@gmail.com; antonius.manurung@mercubuana.ac.id
}

\section{Doi:10.5901/mjss.2015.v6n5s5p18}

\begin{abstract}
The aim of this study is to examine the influence of heroic leadership and learning organization to work achievement with authentic personal branding as mediator. The hypotheses in this study of structural relations are: (1) authentic personal branding will have a direct, positive and significant effect on successful work achievement, (2) authentic personal branding as mediator, heroic leadership will influence work achievement, and (3) organizational learning influences work achievement using authentic personal branding as a mediator. The subjects of this study are 250 leaders of the Tianshi network marketing business who work in various parts in Indonesia. Data collection using a modified work achievement scale of Munandar (2001), Jewell and Siegall (1998), Setiadi, Mokoginta, and Taryadi (2000); heroic leadership scale based on Lowney (2005); organizational learning scale from Senge (2006); and authentic personal branding scale of Rampersad (2008) all constructed by the researcher with a Likert scaling model. Technique of data analysis to test hypotheses models using Structural Equation Model (SEM) with Linear Structural Model (LISREL) version 8.72 by Joreskog and Sorbom (2008). The result of all hypotheses test showing fit to empirical data. $(C F I=0.99 ; R M S E A=0.040 ; \mathrm{GFI}=0.92 ; \mathrm{NFI}=0.98 ; \mathrm{FI}=0.99)$. The structural relationship between variables may be summarized as follows: (1) There is a direct, positive, and significant influence of authentic personal branding with work achievement, indicated by $r=0.63$; $t=10.70$; (2) Heroic leadership with authentic personal branding as mediator exerted a positive and significant influence on work achievement, indicated by $r=0.43$; $t=5.53$; and (3) With authentic personal branding as a mediator, the learning organization had a significant and positive impact on the achievement of successful work performance, shown as $r=0.39 ; t=5.17$.
\end{abstract}

Keywords: authentic personal branding, heroic leadership, learning organization, work achievement

\section{Introduction}

Trends like globalization and technology innovations change the way of managing organization. Organizations nowadays have to struggle with revolutionary trends, such as product or service acceleration and technology changes, global competition, deregulation, demographic changes, and tendency toward people services and information era (Dessler, 2008). Kanther (in Dessler, 2008) sets out that human resource power based is evolving, which position, title, and authority no longer become sufficient tools to what people depend on in their job, otherwise individual's achievement more depend on good suggestion, to act based on those ideas, and in the use of both to get the outcome.

Human resource's role in organization to create value innovation become very crucial and more realized in giving impact to organizational development. One of interesting research and actual is about work achievement. Furthermore, author defines factors that causing decrease of work achievement as a process and condition where employee in relation with the job has lack of: (1) dream, vision, mission, (2) authenticity and specialization, (3) successful measurement, and (4) self-development with outcome oriented. Those process and condition could be described as a person with lack of authentic personal branding. Align with authentic personal branding indicators which defined by Rampersad (2008), i.e.: authenticity, integrity, consistency, specialization, relevance, visibility, persistency, and goodwill. Therefore, either good or bad one's competency, will effects his work achievement, assumed caused by high or low level of his authentic personal branding.

This emerged phenomena and understanding of how important work achievement to be studied is a crucial and urgent in an organization as it directed to allocating resource in a dynamic working environment, rewarding, determining personal contribution level, and to provide feedback for individual work, maintain justice, planning and personal career development.

Authentic personal branding is an important variable to note in further process that assumed will give contribution to work achievement, as it is one of a main factor in determining work achievement and indicator to all personal 
experience in his working environment (Rampersad, 2008).

Heroic leadership is assumed having influence to authentic personal branding and thus influence work achievement. In many ways, leadership related with personal branding because naturally people attracted to follow a leader who well known having commitment to people's interest, who genuinely willing to support and serve his followers in their job, and willing to take responsibility in solving problems as good as possible (Gwee, 2007).

The implementation of learning organization furthermore assumed to have influence to authentic personal branding, in other words, authentic personal branding become mediator of learning organization to work achievement. Basic of this assumption is that if authenticity, integrity, consistency, specialization, relevant, visibility, persistence, and goodwill as criteria to authentic personal branding has clung within a person through continuous improvement, then integrated action plan has to be developed, align with personal ambition and personal brand to attain work achievement goal improvement.

The emerged phenomena that attracted author in doing some research is tendency of more people who running network marketing business, especially Tianshi with One Vision support system, showing, showed a convincing performance even without promoting educational background, occupation, socioeconomic status, work experience, and so on. The leaders were born to be a winner with a fighting spirit were outstanding and never give up attitude, finally managed to become outstanding individuals.

The formulation of the problem in this research is expected to contribute an original and meaningful to the knowledge and understanding of science-related fields, in addition to conveniently indicates the capacity to do research independently, also showed the ability to present the results of research in the form of a concise and convincing documented and presented properly (King \& Margetson, in Soekadji, 2000). The formulation of the main problem in this research: "Is heroic leadership, organizational learning can be used (fit) to predict the authentic personal branding and can further explain the work achievement?"

\section{Literature Review}

\subsection{Work Achievement}

Work achievement is intrinsically multi-dimensional, so there is no single criterion can describe individual's work achievement in organization totality, precisely, and completely. Every criterion has its own strength that can cover weakness of other criteria. That is the reason why we have to include other relevant working aspects to determine these criteria.

Munandar (2001) presents three aspects of work achievement measure: (a) Output; how far the achieved objectives denoting effective measurement, (b) Working behavior; shows the effective behavior, i.e. behavior that can be observed or measured leads to the achievement of the expected results of the work, and (c) personality traits; characteristics that need to be owned by an individual in order to be successful in the job.

In this study, which assessing aspects of work achievement is the subject of the research itself. Author establishes performance appraisal by the subjects themselves because basically the appraisal performance is often conducted in the marketing business Tianshi with One Vision support system for this, according to the actual conditions of the individual under the monitoring and active mentor.

Further understanding of various experts on work performance, in this study, the researcher uses the notion of job achievement proposed by Munandar (2001), in which achievement is regarded as an interaction of individuals' personality traits that were brought into the organizational work system, work behavior are the result of an interaction between personalities within work environment, which is lasted for work, and achievements or output results of individual work. In connection with this study the authors adapt the measuring instrument uses the concept of measuring work achievement based on the theory of Munandar (2001), Setiadi, Mokoginta, and Taryadi (2000), which includes aspects of nature, behavioral aspects, and managerial aspects.

\subsection{Authentic Personal Branding}

Authentic personal branding is variable that giving contribution to work achievement. Authentic personal branding is one of main factor that determines work achievement, and an indicator to one's experiment in his working environment (Rampersad, 2008). Effort to increase authentic personal branding needed as it effects to one's well-being and so organizational effectiveness. Focus of developing authentic personal brandingis to humanize human through working activities, to produce more positive and conducive working environment to increase job achievement. Changing and 
improving work achievement supported by authentic personal branding improvement program.

Hereafter Rampersad (2008) expresses that someone who has strong authentic personal branding posses the following aspects: (1) identifying and sounding authentic, relevant, meaningful, passionate, inspiring, long lasting, and ambitious dreams, (2) responding those dreams with love and passion; (3) know what makes his unique, special, different, and outstanding, (4) recognize and identify excellence and spread out boundaries based on that matter, (5) success with life according to the dreams and do the job he loved and relate with his dreams, and (6) always have selfconfidence and courage to chase the dream, and stand on it giving him top achievement.

Montoya (2005), states: "anyone whose success depends upon or requires the cooperation of another individual or group needs a great personal brand". Hines expresses the importance of authentic personal branding by saying: "consider branding more in line with bringing forth self knowledge and self expression than creation of a cultivated or false self. It is not about selling 'new and improved' future tools; rather it is about discovering the inner and authentic you proclaiming it to your clients. Personal branding is a key to change all things better, with a very potential way to establish professional practices. (Montoya, 2009). Personal branding means identifying and communicating what makes him unique, relevant, and interesting, that differentiate him with others in increasing career or business (Arruda \& Dixson, 2007).

Authentic personal branding model helps professional human performance technology to build effective personal brand of all activities performed. Montoya (2005) and Rampersad (2008), describes the aspects of authentic personal branding is effective, namely (1) Authenticity; (2) Integrity, (3) Consistency (4) Specialization (5) Relevant (6) Visibility (7) Persistence (8) Goodwill.

\subsection{Learning Organization}

Senge (2006) defines learning organization as follow: "Organizations where people continually expand their capacity to create the results they truly desire, where new and expansive patterns of thinking are nurtured, where collective aspiration is set free, and where collective aspiration is set free, and where people are continually learning how to learn together".

Senge (2006) introduce five discipline to become the learning organization:

a) System Thinking: thinking things in a whole in order to be able to see patterns that is repeated to observe and in needs to watch;

b) Personal Mastery: developing competency, spiritual advancement, and creativity to see reality clearly.

c) Mental Model: development of mental model which accentuate values and principles;

d) Shared Vision: sharing vision among organization citizen, where organization's vision becomepersonal vision for each member; and

e) Team Learning: discipline which is established inside learning by promoting two patterns: dialogues and discussions.

\subsection{Heroic Leadership}

Heroic leadership allegedly brings effect on authentic personal branding. To some extent, leadership is closely related to personal branding because basically people would be naturally interested in following a leader who is known to have a commitment to people's interests, who sincerely want to support and serve the followers in their work, and who are willing to assume responsibility in addressing various problems that arise as well as possible (Gwee, 2007). Meanwhile, in regards to the quality of individual heroism, for instance of having courage to confront risks, having enthusiasm, having readiness to face the problem, willingness to sacrifice and to defend the truth, being always admired, and becoming a moral lesson (Yap, 2009). To optimize the above entities, leadership and heroism are incorporated into heroic leadership, in which the leadership that combines the ability to influence and have heroic character, especially in courage. It is not that the leader who should necessarily give courage, but courage itself will determine the quality of leadership (Yap, 2009).

In the further understanding of heroic leadership from various experts, in this study, the author use the notion of heroic leadership by Lowney (2005), i.e:

a) Self-awareness: understanding one's strengths, weaknesses, values, and worldview;

b) Ingenuity: engaging others with a positive;

c) Love: loving attitude confidently innovating and adapting to embrace a changing world; and

d) Heroism: energizing themselves and others through heroic ambitions. 


\section{Methodology}

\subsection{Subject (Population and sample)}

The population in this study is all leaders of marketing business Tianshi network with One Vision support system which was set by the one system management with more than 1000 people. The samples take $25 \%$ of the population (Arikunto, 2000), thus the number of samples in this study are 250 respondents. Sampling based on considerations or purposive sampling, essentially relates to the selection of a representative sample believed to specific populations (Soekadji, 2000).

\subsection{Hypotheses}

Heroic leadership and learning organization can be used (fit) to authentic personal branding and to explain about work achievement.

a) Authentic personal branding will have a direct, positive and significant effect on successful work achievement;

b) Heroic leadership influences work achievement using authentic personal branding as a mediator; and

c) Organizational learning influenceswork achievementusing authentic personal branding as a mediator.

\subsection{Data Analysis Technique}

Technique of the data analysis models to test hypotheses descriptive technique using Structural Equation Model (SEM) with Linear Structural Model (LISREL) version 8.72 by Joreskog and Sorbom (2008) and descriptive statistical analysis techniques are used to give a general overview of the study subjects. For example, a picture of the mean of each variable, the standard deviation of each variable, and so on. Descriptive statistics are calculated by using SPSS/ PC + version 15.

Figure 1: Theory model authentic personal branding as mediator of heroic leadership and learning organization to work achievement.

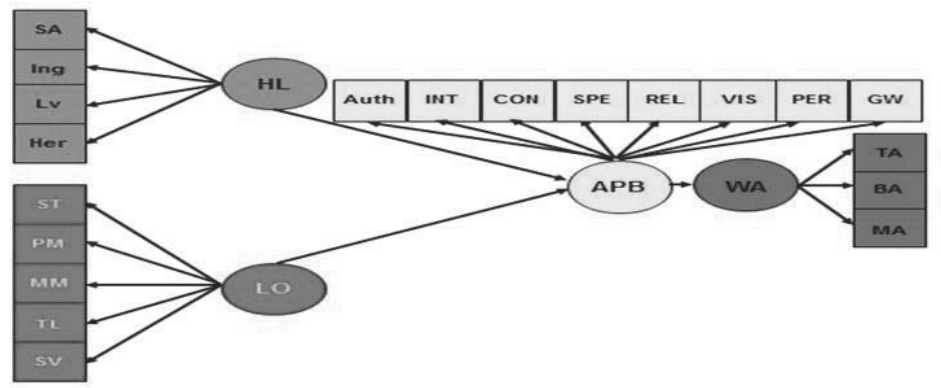

\author{
$\mathrm{KH}=$ Heroic Leadership \\ $\mathrm{KH} 1 \mathrm{l}=$ Self-awareness \\ $\mathrm{KH} 2$ = Ingenuity \\ $\mathrm{KH} 3=$ Love \\ $\mathrm{KH} 4=$ Heroism \\ $\mathrm{OP}=$ Learning Organization \\ OP 1 = System Thinking \\ $\mathrm{OP} 2$ = Personal mastery \\ OP $3=$ Mental Model \\ OP $4=$ Shared vision \\ OP $5=$ Team Learning
}

\author{
APB = Authentic Personal Branding \\ APB $1=$ Authenticity \\ $\mathrm{APB} 2$ = Integrity \\ APB 3 = Consistency \\ APB 4 = Spesialization \\ APB-5 = Relevance \\ APB-6 = Visibility \\ APB-7 = Persistence \\ APB-8 = Goodwill \\ PK = Work Achievement \\ PK1 = Trait Aspect \\ PK2 = Behavior Aspect \\ PK3 = Managerial Aspect
}




\subsection{The Theory Model of Research Instruments}

Heroic leadership scale (four aspects), Organizational learning scale (five aspects), and Work achievement (three aspects), before and after the CFA indicator remains the same and the rest of the item is valid, but the researcher set three items of each aspects which have the highest loading factor. While the authentic personal branding instrument scale originally consists of eight aspects, through the CFA that suggested the four aspects, covering specialties excluded from the model.

This condition can be justified if it is qualitatively analyzed, because according to the researcher in the marketing business network of Tianshi support system with One Vision, there is no particular specialization or special needs. In fact, in every meeting of leaders, it does not always reveal that it takes a certain background or specific specialties to be a successful and excellent leader. Furthermore, in the study, the instrument scale of Authentic personal branding uses seven aspects. So the authentic personal branding scale consists of 21 items, $\mathrm{df}=168 ; \mathrm{x}^{2}=248.02 ; p=0.00 ; \mathrm{CFI}=0.99$; and RMSEA $=0.041$, and thus it is considered fit, because it meets the three conditions of fit size.

\section{Data Analysis and Result}

Based on the result of this research, the correlation matrix is below 0.90 . The matrix shows that there is no very high correlation between independent variables, thus multi-collinearity is not impacted in this research data.

Table 1: Mean, Deviation Standard and Details Reliability

\begin{tabular}{ccccccccc}
\hline Variable & Mean & SD & N & Reliability & KH & OP & APB & PK \\
\hline HL & 4,52 & 0,376 & 12 & 0,895 & 1 & $0,62^{\star \star}$ & $0,67^{* \star}$ & $0,42^{\star *}$ \\
OP & 4,52 & 0,301 & 15 & 0,908 & & 1 & $0,66^{\star *}$ & $0,41^{\star \star}$ \\
APB & 4,40 & 0,209 & 21 & 0,946 & & & 1 & $0,63^{\star \star}$ \\
PK & 4,50 & 0,500 & 9 & 0,916 & & & & 1 \\
\hline
\end{tabular}

**Significant Correlation at $p \leq 0,01$ (2-tailed)

Overall report of CFA, $\chi^{2}, C F I, R M S E A, G F I$, dan RMSR can be seen in table 12 about measurement fit model of each instrument.

Table 2: Summary of CFA Analysis Result

\begin{tabular}{cccccccc}
\hline Var & $\boldsymbol{d f}$ & $\boldsymbol{\chi}^{\mathbf{2}}$ & $\mathbf{p}$ & CFI & RMSEA & GFI & RMSR \\
\hline KH & 48 & 79.26 & 0.003 & 0.99 & 0.048 & 0,95 & 0,010 \\
OP & 252 & 376.76 & 0.000 & 0.97 & 0.006 & 0,78 & 0,019 \\
APB & 168 & 248.02 & 0.000 & 0.99 & 0.041 & 0,92 & 0,010 \\
PK & 18 & 23.19 & 0.180 & 1.00 & 0.032 & 0,98 & 0,006 \\
\hline
\end{tabular}

Description: CFI: $\geq 0,90=$ Good Fit

RMSEA: $\leq 0,08=$ Good Fit

GFI: $\geq 0,90=$ Good Fit

RMSR: $\leq 0,05=$ Good Fit

Source: Sitinjak and Sugiarto (2006: 68-69)

From the analysis above, it shows that all models have met the criteria for the measurement of fit based on predetermined fit index ( $\chi^{2}, \mathrm{CFI}, \mathrm{RMSEA}, \mathrm{GFI}$, and RMSR) and the magnitude of the numbers mentioned above on each instruments involved in this research. Based on the results of the analysis, it can be concluded that the entire measurement model is acceptable as a model that is appropriate (fit) with the data obtained from the field. Therefore, the significance test models can be performed. The significance of test results from the entire measurement models involved in hypotheses testing, are in overall reported in the following table. Loading factor of each latent variable has the value of $t>2.58(p<0.01)$.

It means that the indicators are assumed to be able to measure latent variables of each of tested compatibility (fit), or acceptable as a valid indicator or significant to the possibility of error of under $1 \%$. It means that the fourth measurement model has been carried out in accordance to the constructed theory (fit) with the data from the field 
(manifest variables). On the basis of this analysis, it means that the results can be used to test the formulated hypotheses research. The results of load factor analysis and significance test are outlined in Table 3.

Table 3: Result of Significance Test and Loading Factor to four Research Instruments

\begin{tabular}{llcc}
\hline No & Variabel & t Value & Loading Factor \\
\hline 1 & Heroic Leadership & & \\
& - Self Awareness & 10.38 & 1 \\
& - Ingenuity & 10.14 & 0.95 \\
& - Love & 9.37 & 1 \\
& - Heroism & 7.59 & 1 \\
2 & Learning Organization & & \\
& - System Thinking & 9.91 & 1 \\
& - Personal Mastery & 9.40 & 1 \\
& - Mental Model & 9.82 & 1 \\
& - Shared Vision & 10.83 & 1 \\
& - Team Learning & 10.17 & 0.95 \\
3 & Authentic Personal Branding & 11.80 & \\
& - Authenticity & 12.45 & 1 \\
& - Integrity & 11.73 & 0.99 \\
& - Consistency & 10.92 & 1 \\
& - Relevant & 11.05 & 1 \\
& - Visibility & 12.03 & 1 \\
& - Persistence & 12.47 & 0.99 \\
& - Goodwill & & \\
Work Achievement & 11.78 & 1 \\
& - Trait Aspect & 9.34 & 1 \\
& - Managerial Aspect & 14.02 & 1 \\
\hline
\end{tabular}

The result of the model fit to the hypothetical model shows that the hypothetical model has $\chi^{2}$ fit index $=227.61, p=0.00$; $\mathrm{CFI}=0.99$, and RMSEA $=0,040$. That is a hypothetical model or hypotheses dissertation which is acceptable as a suitable model (fit) with the data from the field. It means that the "Authentic personal branding as a mediator of heroic leadership and organizational learning on work performance can be a good fit for the data." The Hypothetical model can be accepted and fit with the data so that the main demands in this study, which tests the theoretical model's fit in accordance with the data from the field that has been successfully implemented.

Table 4: Hypotheses Model Testing Result Data

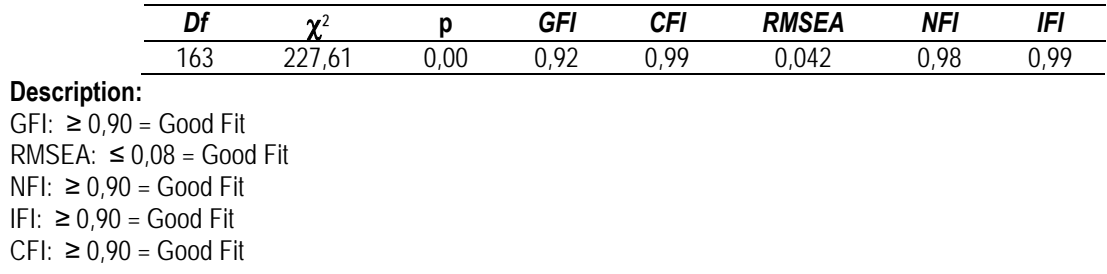

Source: Sitinjak and Sugiarto (2005)

\section{Implication and Conclusion}

The results of significance test (t value) indicates that the coefficient parameter existing in the hypothetical model has the value of $t>2.58(p<0.01)$. It means that the hypotheses tested in this study have a valid and very significant parameter. Thus, the hypothetical model tested in this study fits the data. The results of the hypothetical test are appropriate or accepted as a fit and significant model, meaningful hypotheses in structural relationship, either directly or indirectly from the four research variables, and able to continue testing. The reported results of the hypothetical model which has been 
tested for their suitability (fit), is presented in Appendix E. After testing the hypothetical model, fit (fit/goodness of fit) as depicted above, the structural relationships of hypotheses test between variables can be done through: (a) structural relationship fit test with field data of each hypotheses, and (b) hypotheses test of structural relationship.

Hypotheses 1: Authentic personal branding will have a direct, positive and significant effect on successful work achievement with correlation coefficient is $r=0,63(t=10.70>2,58)$, so the first hypotheses is accepted.

Hypotheses 2: Authentic personal branding as mediator, heroic leadership will influence work achievement, with correlation coefficients $r=0.43(t=5.53>2,58)$, so the second hypotheses is accepted.

Hypotheses 3: Organizational learning influenceswork achievementusing authentic personal branding as a mediator with correlation coefficients $r=0.39(t=5.17>2,58)$, so the third hypotheses is accepted.

The major hypotheses (structural relationships of all variables, as a theoretical model have been tested and fit to the data). The authentic personal branding regarded to be the mediator of heroic leadership and organizational learning on work achievement (1) The total effects (heroic leadership) is 0.43 and 0.43 in indirect effect, so $100 \%$ of the total effect is an indirect effect, or it can be concluded that there is an effect on work achievement of heroic leadership through the mediator of authentic personal branding; (2) The total effects (learning organization) is 0.39 , and indirect effect of 0.39 , so that $100 \%$ of the total-effect is an indirect effect, or it can be concluded that there is a learning organization through the influence of authentic personal branding mediator in work achievement.

Therefore the four intervariable structural relation hypotheses in this research, either direct or indirect between authentic personal branding as mediator to heroic leadership and learning organization together to work achievement can be accepted.

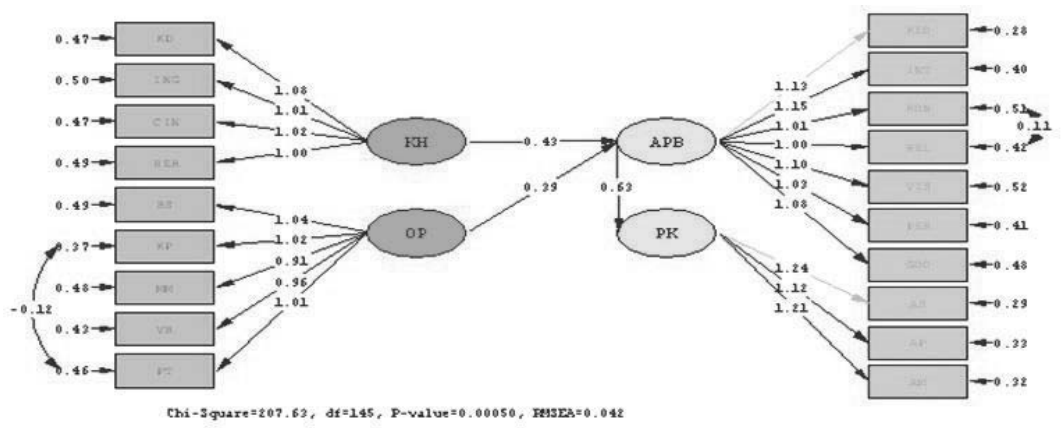

Figure 2: Relationships Among Variables After Testing

\section{Research Limitations}

The results of this study have and bring positive contribution to the world of marketing network, especially regarding work performance of the leaders in Tianshi marketing business network of with One Vision support system, but it is not apart from a variety of obstacles and constraints. For example, it only involves Tianshi network marketing business, coming from only one support system of Tianshi that is One Vision so there is no comparison. Another limitation of this study is due to only examining the subject of research which is focused only on qualified leaders, so again there is no comparison.

The concept of heroic leadership, organizational learning, and authentic personal branding is relatively novel in Indonesia. The third concept has not been widely studied in the field of psychology, and that makes the reference literature for the research is still a few. Therefore, the theories should be studied more broadly in line with the field of psychology.

Determination of the subjects' characteristics in this study in order to determine the respondents has caused the sensor of variables. Methodologically, the number of variables causing variants and covariance sensor is small, which brings impact on the respondents' scores on all the variables involved in this study have reached the maximum value.

\section{References}

Arikunto, S. (2000). Research Management. Jakarta: Rineka Cipta. 
Arruda, W. \& Dixson, K. (2007). Career distinction: stand out by building your brand. New York, John Wiley.

Bhalotia, N., (2003). "Personal branding - me inc.", Article, pp. 7, http://www.brandchannel. com/images/ Papers/Personal Branding Melnc.pdf

Brown, E. M. \& Trevino K. L. (2006), Socialized charismatic leadership, values congruence, and deviance in work groups, Article, Journal of Applied Psychology, Vol.91 No. 4, APA.

Cohen, W.A. (2010). Heroic leaders. Article. Leadership excellence. USA: Provo 27 (8): 17

Creswell, W.J. (1994). Research design, qualitative and quantitative approaches. California: Sage Publications.Inc.

Dessler, G. (2008). Human resource management. NJ: Prentice Hall.

Gwee, J. (2007). Leadership, a way to build personal branding. Seminar, unpublished, Jakarta.

Hines, A. (2004). The personal brand in future. The Journal of Future Studies, Strategic Thinking and Policy: ABI Inform Global, 6 (1), 60-61.

Jewell, N.L. \& Siegall, T.M. (1998), Contemporary industrial - organizational psychology. Illinois: West Publishing.

Joreskog, K. \& Sorbom, D. (2008). Lisrel 8,72 : user's reference guide. Scientific Software International.

Jörg, T. (2010). Rethinking the learning organization. University of Utrecht, The Netherlands, agdjorg@gmail.com.

Kerlinger, F.N. \& Lee, H.B. (2000). Foundation of behavior research (4th ed.). Belmont, CA: Thomson Learning.

Li, K.C. \& Hung, H.C. (2009), The influence of transformational leadership on workplace relationships and job performance. Journal of Social Behavior and Personality, 37(8), 1129-1142.

Lowney, C. (2005). Heroic leadership. Chicago, Illinois: Loyola Press.

Manurung, A.D.R (2001). Relationships between perception of leader power and subordinates performance.Tesis, unpublished, Depok: UI.

Manz., C.C.\&Sims, P.H., Jr. (1989). Superleadership: leading othes to lead themselves. New York: Prentice-Hall.

McCrimmon, M. (2006). Post-heroic leadership: how to succeed in the 21stcentury.Canadian Institute of Management/Institut Canadien De Gestion. www.leadersdirect.com.

Montoya, P. \& Vandehey T. (2009). The brand called you. New York: McGraw-Hill.

Munandar, A.S. (2001). Industry and organizational psychology. Jakarta: publisher UI-Press.

Poell, F.R., Dam V. K. \& Berg D., Van, T. P. (2004).Organising learning in work contexts. Article, Applied Psychology: An International Review, The Netherlands: Tilburg University, Ed. 53 (4) $529-540$.

Rampersad, K.H. (2008). Authentic personal branding: a new blueprint for building and aligning a powerful leadership brand. Jakarta:PPM.

Rampersad, K.H. (2008). Performance improvement. Article, International Society for Performance Improvement, Hoboken, Vol. 47 (6): 34

Robbins, D.B. (2008). What is the good life? positive psychology and the renaissance of humanistic psychology, Journal of The Humanistic Psychologist: Department of Humanities and Human Sciences, Point Park University, 36: 96-112.

Seligman, M. (2006). Handbook of positive psychology. New York: Oxford University.

Senge, M. P. (2006). The fifth discipline: the art and practice of the learning organization.London: Random House-Business Book.

Sitinjak, J.R., Tumpal \& Sugiharto (2006). Lisrel, Yogyakarta: Graha IImu

Snyder, R.C., Lopez, J.S, \& Pedrotti, T.J. (2011).Positive psychology: the scientific and practical explorations of human strengths. Second Edition.California: Sage Publications, Inc.

Soekadji, S. (2000). Compile and evaluate research reports. Jakarta: Penerbit Universitas Indonesia (UI - Press).

Wijayanto, S.H. (2008). Structural equation modeling with LISREL 8.8: concepts and tutorials. Yogyakarta: Graha IImu.

Yap, L (2009). Heroic leaders. Jakarta: Gramedia Pustaka Utama.

Yudhawati, D. (2007). Positive psychology socialization for enhancing human resource and organization quality. Niennial International Conference on I/O Psychology. Yogyakarta: APIO. 